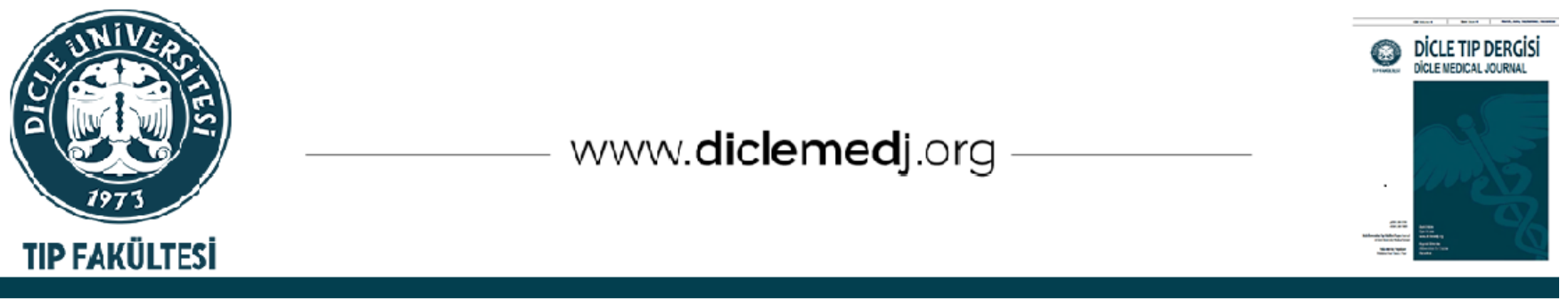

\title{
Kurkuminin Kök Hücre Koruyucu ve Farklılaștırıcı Etkisinde Hipoksi ile İndüklenen Faktör-1 Alfa'nın Rolü
}

\author{
Süleyman İlhan iD 1 \\ 1 Manisa Celal Bayar Üniversitesi, Biyoloji Bölümü, Manisa, Türkiye
}

Geliş: 11.08.2020; Revizyon: 18.11.2020; Kabul Tarihi: 24.11.2020

$\ddot{0} \mathbf{z}$

Amaç: Bu çalışmada, zerdeçal bitkisinden elde edilen kurkuminin kök hücre farklılaştırıcı ve hücre koruyucu etkisinin araştırılmasının yanında, hipoksi ile indüklenen faktör-1 alfa (HIF1- $\alpha$ )'nın bu etkideki rolü araştırılmıştır.

Yöntemler: Kurkuminin koruyucu etkisini araştırmak üzere, fare kemik iliği mezenkimal kök hücreleri (KIMMKH) kurkuminin artan konsantrasyonları ile $(0.5-20 \mu \mathrm{M}) 1$ saat ön muamele edildikten sonra hücrelere 24 saat boyunca 400 $\mu \mathrm{M}$ hidrojen peroksit $\left(\mathrm{H}_{2} \mathrm{O}_{2}\right)$ stresi uygulandı. 24 saat sonunda MTT testi ile hücre canlılı̆̆ı ölçüldü. Oluşan reaktif oksijen türevlerinin (ROT) miktarı ise H2DCFDA boyaması ile belirlendi. Kurkuminin hücre farklılaşması üzerindeki etkilerini belirlemek üzere Alizarin kırmızısı boyası kullanıldı. HIF1- $\alpha$ gen ekspresyon seviyeleri gerçek zamanlı kantitatif polimeraz zincir reaksiyonu kullanılarak belirlendi.

Bulgular: Kurkuminin artan konsantrasyonlarının hücre canlılı̆g üzerinde etkisinin olmadığı (p>0.05), $0.5 \mu \mathrm{M}$ kurkuminle 1 saat ön muamele edilen KIMKH'lerin hücre canlılığının ise $400 \mu \mathrm{M} \mathrm{H}_{2} \mathrm{O}_{2}$ uygulanan hücrelere oranla arttığı belirlendi $(\mathrm{p}<0.05)$. Kurkuminle ön muamele edilen KIMKH grubundaki ROT miktarının, sadece $\mathrm{H}_{2} \mathrm{O}_{2}$ uygulanan hücrelere göre azaldığı, hücre farklılaşma miktarının ise arttığı tespit edildi. $0.5 \mu \mathrm{M}$ ve $1 \mu \mathrm{M}$ kurkumin ön muamelesi sonucu KIMKH'lerdeki HIF1- $\alpha$ mRNA miktarları $400 \mu \mathrm{M} \mathrm{H}_{2} \mathrm{O}_{2}$ uygulanan hücrelere göre sırasıyla 1.86 ve 2.24 kat azalış gösterdi $(\mathrm{p}<0.05)$.

Sonuç: Bu çalışma, kurkuminin gerek KIMKH canlılığı üzerinde etkisinin olmayışı, gerekse ROT miktarında azalışa neden olmasından dolayı KIMKH koruyucu etkisinin olduğunu ve bu etkileri sonucunda HIF1- $\alpha$ mRNA miktarlarının azaldığı belirlenmiştir. KİMKH'lerin reaktif oksijen türevlerinin yoğun olduğu transplantasyon ortamına konulmadan önce kurkuminle muamele edilmesi, KìKH'lerin canlılığını korumasını sağlayacağı gibi, hücrelerin tedavi edici özelliklerinin de korunmasına yardımcı olacağı düşünülmektedir.

Anahtar kelimeler: Kurkumin, kemik iliği mezenkimal kök hücreleri, hücre farklılaşması, HIF1- $\alpha$.

\section{DOI: 10.5798/dicletip.850462}

Correspondence / Yazışma Adresi: Süleyman İlhan, Manisa Celal Bayar Üniversitesi, Biyoloji Bölümü, Muradiye, Manisa, Türkiye e-mail: suleyman.ilhan@cbu.edu.tr 


\title{
The Role of Hypoxia-inducible Factor-1 in Stem Cell Protecting and Differentiating Effect of Curcumin
}

\begin{abstract}
Objective: To investigate the role of HIF1- $\alpha$ in the stem cell differentiation and cell protective effect of curcumin.

Methods: Mouse bone marrow mesenchymal stem cells (MSCs) were pretreated with increasing concentrations of curcumin $(0.5-20 \mu \mathrm{M})$ for 1 hour, then $400 \mu \mathrm{M}$ hydrogen peroxide $\left(\mathrm{H}_{2} \mathrm{O}_{2}\right)$ stress was applied and cell viability was measured by MTT test at $24 \mathrm{~h}$. The amount of reactive oxygen species (ROS) was determined by H2DCFDA staining. Alizarin red dye was used to determine the effects of curcumin on cell differentiation. HIF1- $\alpha$ gene expression levels were determined using qRT-PCR.

Results: Increasing concentrations of curcumin had no effect on cell viability ( $p>0.05)$. The cell viability of MSCs pretreated with $0.5 \mu \mathrm{M}$ curcumin for 1 hour increased compared to cells treated with only $400 \mu \mathrm{M} \mathrm{H}_{2} \mathrm{O}_{2}(\mathrm{p}<0.05)$. In the curcumin pretreatment group, the amount of ROS was found to be significantly reduced and cell differentiation levels were increased $(p<0.05)$. The amount of HIF1- $\alpha$ mRNA levels were found to be decreased by 1.86 and 2.24 fold, respectively in $0.5 \mu \mathrm{M}$ and $1 \mu \mathrm{M}$ curcumin pretreated cells $(\mathrm{p}<0.05)$.

Conclusion: In this study, it has been shown that curcumin has a protective effect on MSCs. It is thought that treating MSCs with curcumin before they are put into the transplantation media with high levels of ROS will not only maintain the vitality of MSCs, but also help to preserve the therapeutic properties of the cells.
\end{abstract}

Keywords: Curcumin, bone marrow stem cell, stem cell differentiation, HIF1- $\alpha$.

\section{GíRiş}

Kıkırdak yaralanmaları, eklem hastalıkları, osteokondral hasarlar (hem eklem kıkırdağı hem de kemikte hasarın birlikte görülmesi) gibi durumlar günümüzde oldukça yaygın görülmekle beraber bu hastalıkların görülme sıklığı gittikçe artmaktadır. Kemiğin kendini tamir yeteneği olsa da kıkırdak dokuda damarlar ve sinirler olmadığından bu dokunun yeteneği oldukça kısıtlıdır. $\mathrm{Bu}$ nedenle araştırmacılar bu tip hastalıkların tedavisi için yeni çözüm arayışları içindedir ${ }^{1}$.

Günümüzde mezenkimal kök hücrelerinin (MKH) terapötik potansiyeli hem klinik öncesi hem de klinik çalışmalarda kanıtlanmıştır ve iskemik hastalıklar ve doku hasarı için umut verici bir terapi ortaya koymaktadır ${ }^{2,3}$. Kök hücrelerin tanımlayıcı ve benzersiz özellikleri, bir organizmanın yaşam süresi boyunca doku homeostazını sürdürmelerini sağlayan kendi kendini yenileme ve multipotent farklılaşma kapasiteleridir. Kemik iliği kaynaklı mezenkimal kök hücreler (KIMKH) en iyi tanımlanmış MKH popülasyonudur. Kök hücrelerin kullanıldığı hücresel tedavide amaç; hasar gören veya doğru fonksiyon göstermeyen bir hücre veya doku işlevini kök hücreleri kullanarak, tamir etmek veya yenilemektir ${ }^{5}$. Bu amaç için "zarar görmüş olan dokuya, o dokunun fonksiyonunu yerine getirmeye yetecek sayı ve kalitede, kök hücrelerin aktarılması" gerekmektedir. Ancak, transplante edilen MKH'lerin canlılığını uzun süre koruyamamaları klinik kullanımlarında karşılaş̧lan en önemli zorluklardan biridir ${ }^{5,6}$.

MKH'lerin hücre canlılığını etkileyen en önemli faktörlerden biri hipoksi kaynaklı oksidatif strestir ve oluşan reaktif oksijen türevleri (ROT) transplante edilen MKH'lerin farklılaşma özelliklerini olumsuz yönde etkilemektedir ${ }^{7,8}$. Hipoksi ile indüklenen faktör-1 alfa (HIF1- $\alpha$ ), oksijen seviyelerine tepkide kritik bir rol oynayan bir transkripsiyon faktörüdür. HIF- $1 \alpha$ glikoliz, apoptoz, anjiyogenez ve hücre proliferasyonu gibi süreçlerde rol alan çok sayıda hedef geni düzenler ${ }^{9,10}$. MKH'ler hipoksik koşullara ve ROT'a bu kadar duyarlı olduklarından, transplante edilen MKH'lerin 
canlılığını ve farklılaşma özelliklerini pozitif yönde etkileyecek yeni bileșenlerin ortaya konması gerekmektedir. Keşfedilecek yeni antioksidan moleküller ROT hasarını önleyerek MKH tranplantasyonunun daha başarılı bir şekilde gerçekleşmesini sağlayabilir.

Günümüzde doğal bileșenlerin yaşlanma, kanser ve dejeneratif hastalıklara karşı kullanımına ilgi giderek artmaktadır. Kurkumin, tropikal Curcuma longa bitkisinin rizomlarından elde edilen doğal bir polifenoldür ${ }^{11}$. Antikanser, antimikrobiyal, antiinflamatuar, anti bakteriyel aktiviteleri olan bir molekül olan kurkuminin antioksidan kapasitesi E veya C vitamininden 100 kat daha güçlüdür. Kurkuminin oksidatif hasara ve mekanizmalarına karşı koruyucu etkisi çeşitli hücre tiplerinde bildirilmiștir12-15. Ancak oksidatif hücre hasarı sırasında kemik oluşumunun baskılanmasının kurkumin tarafından tersine çevrilip çevrilemeyeceği ve HIF1- $\alpha$ 'nın kurkuminin işlevi ile ilişkili olup olmadığı bilinmemektedir. $\mathrm{Bu}$ çalışmada, kurkumin ile ön muamelenin KİMKH'ler üzerindeki hücre koruyucu ve hücre farklılaştırıcı etkileri olup olmadığ araştırılmıștır. Ayrıca, kurkuminin bu etkilerini gerçekleştirirken KIMKH'lerde HIF1- $\alpha$ gen ekspresyon seviyelerini etkileyip etkilemediği araştırılmıştır.

\section{YÖNTEMLER}

\section{Kurkuminin hazırlanması}

Kurkumin Sigma-Aldrich

(C1386-5G)

firmasından satın alındı. $1 \mathrm{mg}$ kurkumin $10 \mathrm{ml}$ etanolde çözülerek $0.1 \mathrm{mg} / \mathrm{mL}$ 'lik stok solüsyon hazırlandı. Elde edilen solüsyon $0.22 \mu$ m'lik filtreden geçirilerek steril edildi ve $-20^{\circ} \mathrm{C}$ 'de alikotlanarak saklandı.

\section{Hücrelerin kültüre edilmesi}

Fare kemik iliği mezenkimal hücreleri (Cat. No:66096-23, Celprogen, Torrance, CA, USA)
Manisa Celal Bayar Üniversitesi, Biyoloji Bölümü'nün hücre hatları stoğundan temin edildi. Hücreler, \%10 fetal sığır serumu (SigmaAldrich), \%0.02 gentamisin içeren DMEM (glukoz ve glutamin içermeyen) besiyerinde (Thermo Fisher Scientific) kültüre edildi. Mikrobiyal enfeksiyonu önlemek için besiyerine $\% 1$ penisilin-streptomisin (Sigma-Aldrich) ilave edildi. Deney süresince hücreler $37^{\circ} \mathrm{C}$ 'de $\% 5^{\prime}$ lik $\mathrm{CO}_{2}$ 'li inkübatörlerde (Nuaire) çoğaltıldı. Osteojenik farklılaşmayı indüklemek amacıyla DMEM besiyerine $50 \mathrm{mg} / \mathrm{mL}$ askorbik asit, 10 nM deksametazon, $10 \mathrm{mM}$ b-gliserofosfat (Sigma-Aldrich) eklendi.

Hücre canlılığının MTT yöntemiyle belirlenmesi MTT [3-(4,5-dimetiltiyazol2-yl)-2,5difeniltetrazolyum-bromür], canlı hücreler tarafından koyu mor renge çevrilen sarı renkli bir tetrazolyum tuzudur. Dört farkl deney grubuyla MTT testi gerçekleştirildi. Bunlar; 1. grup: hiçbir uygulama yapılmayan kontrol hücreleri, 2. grup: kurkuminin artan konsantrasyonlariyla $\quad(0.5-20 \mu \mathrm{M}) \quad 24$ saat inkübe edilen hücreler, 3 . grup: hidrojen peroksitin $\left(\mathrm{H}_{2} \mathrm{O}_{2}\right)$ artan konsantrasyonlarıyla (200-1000 $\mu \mathrm{M}) 24$ saat inkübe edilen hücreler ve 4 . grup: 1 saat kurkumin ile ön muamele edildikten sonra $400 \mu \mathrm{M} \mathrm{H}_{2} \mathrm{O}_{2}$ stresi uygulanan hücrelerdir. $\mathrm{H}_{2} \mathrm{O}_{2}$ stresi olarak en düșük $\mathrm{H}_{2} \mathrm{O}_{2}$ konsantrasyonu $(200 \mu \mathrm{M})$ ya da en yüksek $\mathrm{H}_{2} \mathrm{O}_{2}$ konsantrasyonu $(1000 \mu \mathrm{M})$ yerine, bu dozlar arasında bulunan $400 \mu \mathrm{M}$ seçilmiştir. $\mathrm{Bu}$ uygulamalar sonunda hücrelere $20 \mu \mathrm{L}$ MTT (Sigma-Aldrich) solüsyonu eklenerek 4 saat $37^{\circ} \mathrm{C}^{\prime} \mathrm{de}$ inkübe edildi. 4 saat sonunda kuyucuklar boşaltıldı ve $200 \mu \mathrm{L}$ dimetilsülfoksit (Applichem) eklendi. Çalkalayıcıda $5 \mathrm{dk}$ inkübasyon yapıldıktan sonra kuyucukların absorbans değerleri 570-690 nm referans aralığında mikro plaka okuyucuda (Tecan, Infinite 200 Pro) ölçüldü. Her konsantrasyon 3 farklı kuyucukta çalışıldı ve deneyler $3 \mathrm{kez}$ tekrar edildi. 


\section{Reaktif oksijen türev miktarlarının ölçümü}

Hücredeki reaktif oksijen türevlerinin ölçümü için 2',7'-diklorohidrofloresan diasetat (H2DCFDA) boyası kullanıldı. H2DCFDA hücre içindeki reaktif oksijen türevleri varlığında yeşil floresans ışıma yapan bir boyadır. Reaktif oksijen türevleri miktarı arttıkça yeșile boyanan hücre miktarı da artar. Hücreler (105 hücre/kuyucuk) 6 kuyucuklu plakalara ekilerek kurkumin, $\mathrm{H}_{2} \mathrm{O}_{2}$ ve ön kurkumin uygulamalarıyla 24 saat inkübe edildi. 24 saat sonunda kuyucuklara $2 \mathrm{mM}$ konsantrasyonda H2DCFDA boyası eklenerek $37^{\circ} \mathrm{C}^{\prime}$ de 20 dakika karanlıkta inkübasyona bırakıldı. Daha sonra hücreler PBS ile 2 kez yıkandı ve hücre içi ROT birikimi floresans mikroskopta (Olympus IX53) (490/520 nm) görüntülendi.

\section{Minerilizasyon ve kalsiyum miktar tayini}

Minerilizasyonun belirlenmesi için KIMKH'ler 14 gün osteojenik besiyerinde kültüre edildi. Kalsiyum birikimi Alizarin kırmızısı boyası (Sigma) kullanılarak belirlendi. İnkübasyon süresinin sonunda hücreler $\% 10$ 'luk formalin solüsyonuyla 30 dakika inkübe dildi ve distile suyla yıkama yapıldı. Fiksasyonun sonunda, hücrelere $\% 10$ 'luk Alizarin kırmızısı eklenerek 45 dakika oda sıcaklığında inkübe edildi. Ardından distile suyla yıkanan hücreler mikroskopta görüntülendi (Olympus IX53, 570 nm). Kalsifikasyonun ölçülmesi için kültürlere $\% 10$ setilpiridinyum klorür (Sigma-Aldrich) ilave edildi ve 10 dakika inkübe edildi. Numunelerin absorbansı 570 nm'de ölçüldü.

\section{HIF1- $\alpha$ mRNA ekspresyon seviyelerinin belirlenmesi}

Total RNA izolasyonu için Trizol ajanı kullanıldı (Qiagen). İzole edilen RNA'ların kalitesi agaroz jel elektroforezi ile belirlendi. Gliseraldehit-3fosfat dehidrogenaz (GAPDH, Real-Time ${ }^{\mathrm{TM}}$ qPCR Primer Assay) pozitif kontrol olarak kullanıldı. Quantitect reverse transcription kiti (Qiagen) kullanılarak RNA cDNA'ya çevrildi. HIF1- $\alpha$ için qRT-PCR işlemi, Light Cycler 480 cihazında
(Roche Applied Science) gerçekleştirildi. PCR reaksiyonu $12.5 \mu \mathrm{L}$ RT2 SYBR Green qPCR Master Mix, $10.5 \mu \mathrm{L}$ DNaz ve RNaz içermeyen su, $1 \mu \mathrm{L}$ gen-spesifik PCR primer solüsyonu $1 \mu \mathrm{L}$ cDNA örneği içerecek şekilde hazırlandı. PCR koşulları $95^{\circ} \mathrm{C}^{\prime} \mathrm{de} 10 \mathrm{dk}, 95^{\circ} \mathrm{C}$ 'de 15 saniye, 60 ${ }^{\circ} \mathrm{C}^{\prime} \mathrm{de} 1 \mathrm{dk}$ ve 40 döngü olacak șekilde belirlendi.

\section{İstatistiksel Analiz}

İstatistiksel analiz Graphpad Prism 5 yazılımı kullanılarak yapıldı. Elde edilen verilere tek yönlü varyans analizi (ANOVA) ardından Dunnett's t-test uyguland. $\mathrm{p}<0.05$ olan değerler istatistiksel olarak anlamlı kabul edildi.

\section{BULGULAR}

\section{Kurkuminin hücre koruyucu etkilerinin belirlenmesi}

Kurkuminin KIMKH'ler üzerindeki hücre koruyucu etkilerini belirlemek için, öncelikle ayrı ayrı kurkumin ve $\mathrm{H}_{2} \mathrm{O}_{2}$ 'nin hücre canlllı̆̆ üzerindeki etkileri MTT yöntemiyle araştırıldı. 1. grup KIMKH'ler kurkuminin artan konsantrasyonlarıyla 24 saat inkübe edildi ve hücre canlılığına ait grafik Şekil 1A'da gösterildi. Uygulanan en yüksek kurkumin konsantrasyonunda dahi KIMKH'lerin canlılığında bir değişim belirlenmedi ( $p>0.05)$. $\mathrm{H}_{2} \mathrm{O}_{2}$ 'nin KIMKH'lerin canlllığına etkilerini araştırmak üzere hücreler $\mathrm{H}_{2} \mathrm{O}_{2}$ 'nin artan konsantrasyonlariyla 24 saat muamele edildi ve sonuçlar Şekil 1B'de gösterildi. $\mathrm{H}_{2} \mathrm{O}_{2}$ 'nin 200,400 , 800 ve $1000 \mu \mathrm{M}$ konsantrasyonlarıla hücre canlılığında sırasıyla $\% 89, \% 91, \% 92$ ve $\% 93$ azalış tespit edildi $\left({ }^{*} \mathrm{p}<0.05\right)$.
A

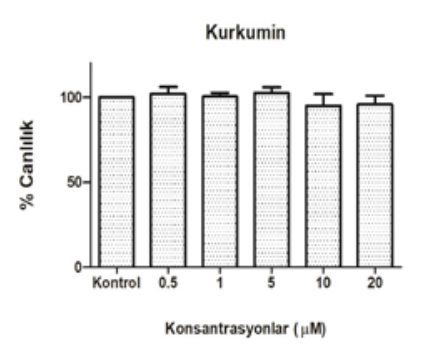

B

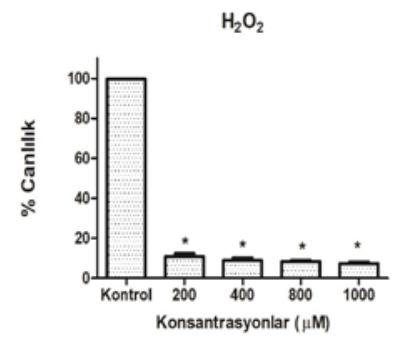

Şekil 1: Kurkuminin (A) ve $\mathrm{H}_{2} \mathrm{O}_{2}$ 'nin (B) artan konsantrasyonlarıyla 24 saat inkübe edilen KìMK'lere ait canlılık grafiği $\left(\mathrm{p}^{*}<0.05\right)$. 
$0.5 \mu \mathrm{M}$ veya $1 \mu \mathrm{M}$ kurkuminle 1 saat ön muamele edilen hücrelere $400 \mu \mathrm{M} \quad \mathrm{H}_{2} \mathrm{O}_{2}$ eklenmesi sonucu, hücrelerdeki canlılık miktarlarının sadece $\mathrm{H}_{2} \mathrm{O}_{2}$ uygulanan hücrelere oranla \%80 ve \%83 daha fazla olduğu belirlendi (Şekil 2, *p<0.05).

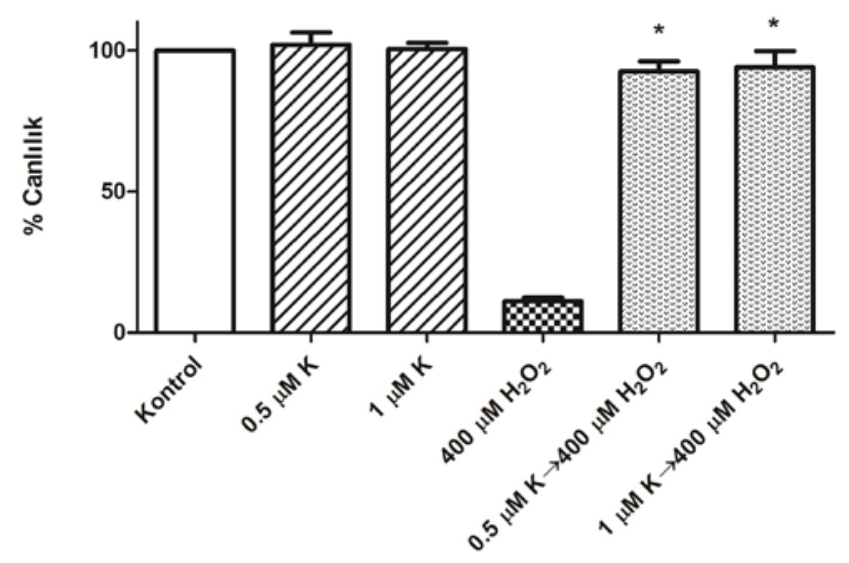

Şekil 2: Kurkuminin KiMKH'ler üzerindeki canlılığı koruyucu etkilerini gösteren grafik, 24. saat (K: kurkumin, ${ }^{*} \mathrm{p}<0.05$, sadece $\mathrm{H}_{2} \mathrm{O}_{2}$ uygulanan hücrelere göre).

\section{Reaktif oksijen türevlerinin ölçülmesi}

Kontrol grubu ve $0.5 \mu \mathrm{M}$ kurkuminle muamele edilen hücrelerde H2DCFDA boyaması sonucu, floresan ışıma gözlenmezken, $400 \mu \mathrm{M} \mathrm{H} \mathrm{H}_{2} \mathrm{O}_{2}$ ile inkübe edilen hücrelerde reaktif oksijen türevlerinin artışı nedeniyle floresan ışıma gözlendi (Şekil 3). Bir saat 0.5 $\mu \mathrm{M}$ kurkuminle ön muamele edildikten sonra $400 \mu \mathrm{M} \mathrm{H}_{2} \mathrm{O}_{2}$ ile inkübe edilen hücrelerde ise kurkuminin koruyucu etkisi sonucu floresan ışımada yani ROT miktarında azalma gözlendi (Şekil 3).

\section{Kurkuminin hücre farklılaşması üzerindeki etkileri}

Osteojenik farklılaşma besiyerinde 14 gün boyunca inkübe edilen kontrol hücreleri Alizerin kırmızısı boyası ile boyanarak farklılaşmanın gerçekleşip gerçekleşmediği kontrol edildi. Osteosite farklılaşmış hücreler $0.5 \mu \mathrm{M}$ kurkuminle 24 saat inkübe edildiğinde, bu gruptaki hücrelerin alizarin kırmızısı ile boyandığı gözlendi (Şekil 4). $400 \mu \mathrm{M} \mathrm{H}_{2} \mathrm{O}_{2}$ ile inkübe edilen farklılașmış hücrelerin ise şekillerinin bozulduğu ve alizarin kırmızısı ile boyanmadıkları belirlendi (Şekil 4). $0.5 \mu \mathrm{M}$ kurkuminle 1 saat ön muamele edilen ve ardından $400 \mu \mathrm{M} \mathrm{H}_{2} \mathrm{O}_{2}$ eklenen hücre grubunda ise, sadece $400 \mu \mathrm{M} \mathrm{H} \mathrm{H}_{2} \mathrm{O}_{2}$ ile muamele edilen hücrelere göre Alizarin kırmızısı boyanmasında anlamlı artış olduğu tespit edildi (Şekil 4).

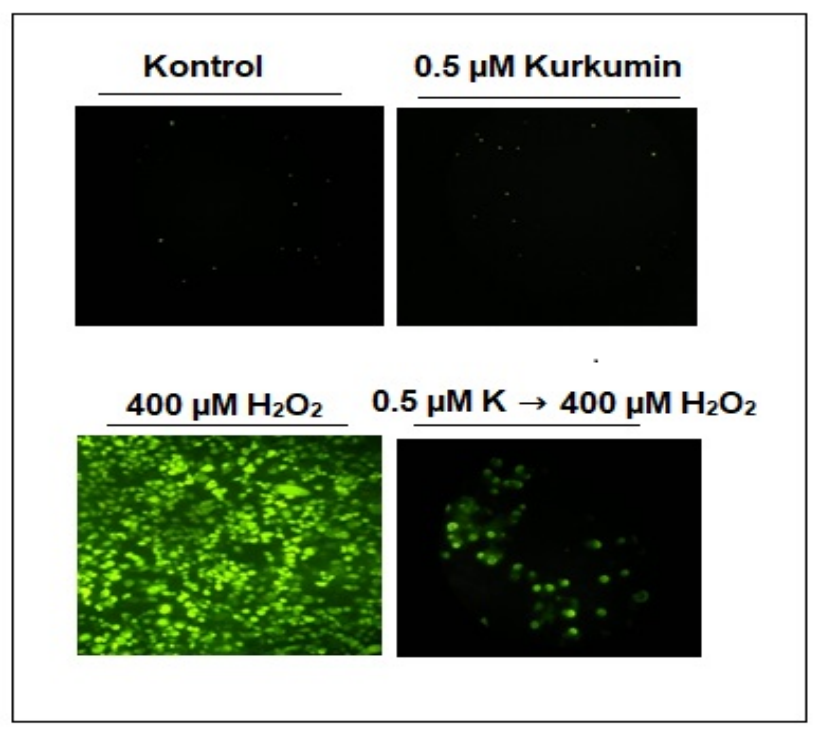

Şekil 3: Kurkuminin KİMKH'lerindeki reaktif oksijen türevlerini azaltıcı etkisi (K: kurkumin).

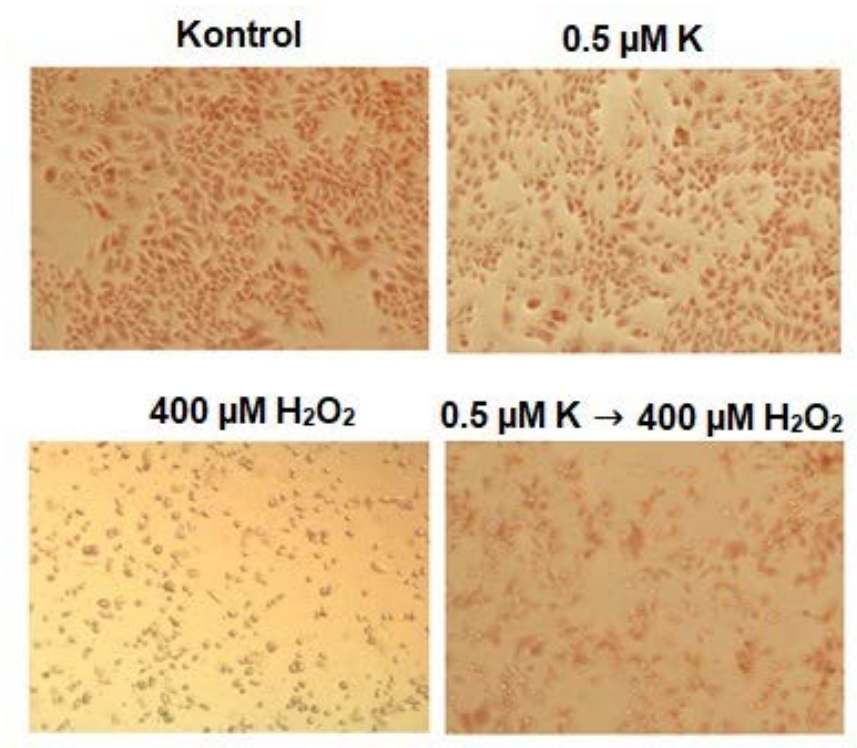

Şekil 4: $0.5 \mu \mathrm{M}$ kurkuminle 1 saat ön muamele edilen ve ardından $400 \mu \mathrm{M} \mathrm{H}_{2} \mathrm{O}_{2}$ uygulanan hücre grubunda sadece $400 \mu \mathrm{M} \mathrm{H}_{2} \mathrm{O}_{2}$ ile muamele edilen hücrelere göre Alizarin kırmızısı boyanmasında gözlenen anlamlı artış (10X). 


\section{HIF1- $\alpha$ mRNA ekspresyonu}

Kurkuminin HIF1- $\alpha$ mRNA ekspresyonu üzerindeki etkileri qRT-PCR ile araştırıldı. Şekil 5'de görüldüğü gibi, yalnızca $\mathrm{H}_{2} \mathrm{O}_{2}$ ile muamele edilen hücre grubunda HIF1- $\alpha$ mRNA ekspresyonunda anlamlı artış belirlenmiştir (*p<0.05). $0.5 \mu \mathrm{M}$ ve $1 \mu \mathrm{M}$ kurkumin ön muamelesi ardından $400 \mu \mathrm{M} \mathrm{H}_{2} \mathrm{O}_{2}$ eklenen KIMKH'lerde ise HIF1- $\alpha$ mRNA ekspresyonunda sırasıyla 1.86 ve 2.24 kat azalış tespit edilmiştir (Şekil 5, ${ }^{*} \mathrm{p}<0.05$, yalnızca $\mathrm{H}_{2} \mathrm{O}_{2}$ uygulanan grup).

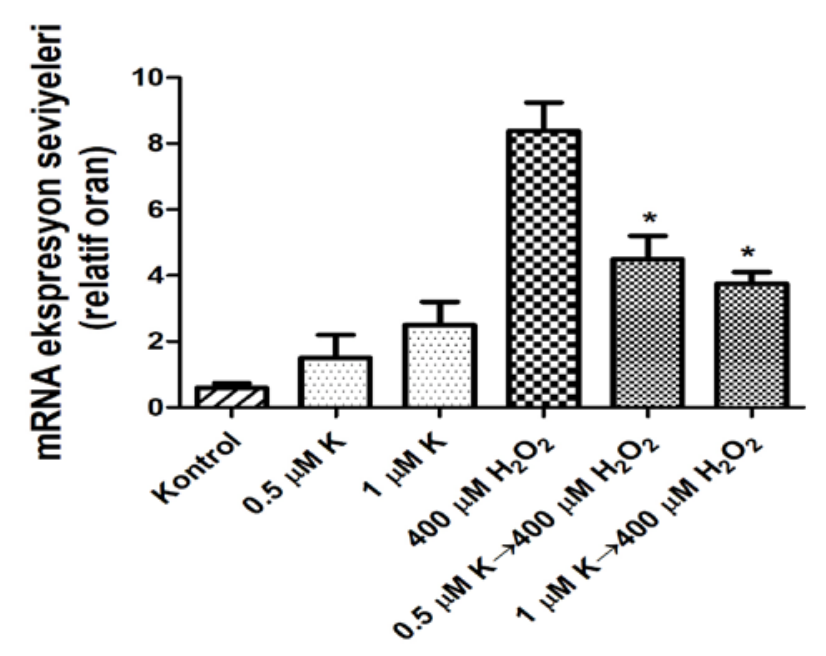

Şekil 5: KIMKH'lerde $0.5 \mu \mathrm{M}$ kurkumin ön muamelesi sonucunda HIF1- $\alpha$ mRNA ekspresyonunda meydana gelen azalış (K: kurkumin, ${ }^{*} \mathrm{p}<0.05$, sadece $\mathrm{H}_{2} \mathrm{O}_{2}$ uygulanan hücrelere göre).

\section{TARTIŞMA}

Kurkuminin, kök hücre farklılaşmasının aktif rol oynadığı osteoporoz, osteoliz ve osteosarkom gibi hastalıklar üzerinde etkili olduğu gösterilmiştir ${ }^{13}$. Ancak bu etkilerini KIMKH'lerde hangi mekanizmalar üzerinden gösterdiği henüz net olarak bilinmemektedir. Ormond ve ark. ${ }^{14}$ kurkuminin kök hücrelerle birlikte verildiğinde omurga yaralanmalarını iyileştirici etkisi olduğunu ve kök hücre canlılığını olumlu yönde etkilediğini göstermişlerdir.

$\mathrm{Bu}$ çalışmada öncelikle kurkuminin KİMKH'lerin canlılığı üzerindeki etkisi araştırılmıştır. MTT sonuçlarına göre, kurkumin 24 saatte test edilen en yüksek konsantrasyonda bile hücre canlılığı üzerinde anlamlı bir etki göstermemiştir. Kurkuminin potansiyel hücre koruyucu etkisinin test edilebilmesi için KİMKH'ler öncelikle hücre içi ani ROT artışına sebep olan $\mathrm{H}_{2} \mathrm{O}_{2}$ ile muamele edilmiş ve ardından hücre ROT miktarı ölçülmüştür. Yüksek stabilitesi ve hücre zarlarından kolayca geçebilmesi nedeniyle $\mathrm{H}_{2} \mathrm{O}_{2}$, in vitro oksidatif stresi taklit etmek için bir oksidan olarak kullanılmaktadır. Önceki çalışmalarla paralel olarak $\mathrm{H}_{2} \mathrm{O}_{2}$ KİMKH'lerin canlılı̆̆ üzerinde negatif etkiye yol açmış ve hücre içi ROT miktarlarında artışa neden olmuştur ${ }^{15}$. KIMKH'lere 1 saat kurkumin ön uygulaması yapıldıktan sonra $\mathrm{H}_{2} \mathrm{O}_{2}$ stresi uygulanıp, tekrar ROT miktarları ölçüldüğünde ise ROT miktarlarının anlamlı derecede azaldığını göstermiștir. Kurkuminin, oksidatif hasar üretimini önlemek için çok çeşitli hücresel hedef ve sinyal yolaklarını düzenlediği bildirilmiștir. Kurkuminin direkt ve dolaylı antioksidan aktiviteleri olduğu bilinmektedir. Kurkuminin ROT temizleme kapasitesi (doğrudan antioksidan etki), temel olarak, bir metilen grubu aracılığıyla bağlanan iki ferulik asit ünitesinin bis- $\alpha, \beta$-doymamış $\beta$-diketonu yapısına atfedilmektedir. Buna ek olarak kurkumin, çekirdeğe göç eden ve antioksidan enzimlerin ekspresyonunu indükleyen Nrf2 salglayarak Keap1'in tiyol gruplarını değiştirebildiği gösterilmiştir (dolaylı antioksidan etki) ${ }^{16}$.

Elde edilen bulgular, kurkuminin gerek KİMKH'lerin canlılığı üzerinde öldürücü etkisinin olmayışı, gerekse hücre içi ROT miktarlarında azalışa neden olması nedeniyle kök hücre koruyucu etkisinin olduğunu doğrulamaktadır. Benzer şekilde, Qi ve ark., preosteoblastik MC3T3-E1 hücrelerinde kurkuminin $\mathrm{H}_{2} \mathrm{O}_{2}$ kaynaklı oksidatif stresi azalttığını belirlemișlerdi ${ }^{17}$. Liu ve ark. ise, adipoz kaynaklı kök hücrelerde kurkuminin 
oksidatif stres hasarına toleransı arttırdığını ve miyokardiyal onarım için kök hücrelerin terapötik potansiyelinin artmasına neden olduğunu göstermişlerdir ${ }^{18}$.

Kurkuminin kök hücrelerinin canlılığını koruyucu etkilerinin yanı sıra hücre farklılaşmasını arttırıcı etkilerinin araştırılması da önemli bir parametredir. $\mathrm{Bu}$ etkinin araştırılması amacıyla kök hücreler osteojenik ve kondrojenik farklılaştırma ortamlarında 14 gün inkübe edildi. Ardından farklılaşan hücrelerin bir grubuna sadece kurkumin, bir grubuna sadece $\mathrm{H}_{2} \mathrm{O}_{2}$, diğer bir grubuna ise 1 saat kurkumin, ardından $\mathrm{H}_{2} \mathrm{O}_{2}$ stresi uygulandı. $\mathrm{H}_{2} \mathrm{O}_{2}$ her iki hücre grubunda da kök hücrelerinin farklılaşmasını baskılarken, kurkuminin hücre farklılaşmasını pozitif yönde etkilediği görüldü. 1 saat kurkumin ön muamelesi yapılan gruptaki hücrelerde ise osteojenik hücrelere farklılaşma miktarının sadece $\mathrm{H}_{2} \mathrm{O}_{2}$ uygulanan gruba göre anlaml derecede arttığı gözlendi. $\mathrm{Bu}$ bulgular kurkuminin hücre farklılaşmasını desteklediğini açıkça göstermektedir. Önceki çalışmalarda kurkuminin pre-osteoblastik MC3T3-E1 hücrelerinde osteogenez ilişkili genlerin ekspresyonunu arttırdığını ve kalsiyum minerilizasyonunu arttırarak hücre farklılaşmasını desteklediği gösterilmiștir ${ }^{17}$. Wang ve ark., kurkuminin $\mathrm{H}_{2} \mathrm{O}_{2}$ tarafindan inhibe edilen insan adipoz kaynaklı MKH'lerin osteoblast farklılaşmasını Wnt/b-katenin sinyalizasyonu üzerinden arttırdığını göstermiştir ${ }^{19}$.

$\mathrm{Bu}$ çalışmada kurkuminin hücre koruyucu ve farklılaştırıcı etkilerini gerçekleștirirken HIF1- $\alpha$ mRNA ekspresyonu üzerinde ne gibi etkileri olduğu araștırılmıștır. ROT'un HIF1- $\alpha$ sinyalizasyonu ile nasıl etkileşime girdiğine ve HIF1- $\alpha$ ekspresyonunu nasıl değiştirdiğine dair birkaç hipotez vardır. Bu mekanizmalardan biri $\mathrm{H}_{2} \mathrm{O}_{2}$ nin ferröz demiri $\left(\mathrm{Fe}^{+2}\right)$ ferrik demirli şekline $\left(\mathrm{Fe}^{+3}\right) \quad$ oksitleyerek HIF1- $\alpha$ hidroksilasyon enzimlerine, prolil hidroksilazlara engellemesidir. (PH) Diğer bir mekanizma, askorbatın ferrik demirin indirgenmesinde ve/veya askorbatın doğrudan PH'lere bağlanmasını engellemede serbest radikal temizleyici olarak yer almasıdır. ROT artarsa, HIF1- $\alpha$ hidroksilasyonu artacaktır. ROT'un HIF1 yolunu etkileyebileceği diğer bir mekanizma, oksijenin doğrudan PH'lere bağlanması veya $\mathrm{PH}$ fosforilasyonunun değiştirmesidir ${ }^{20}$.

Bulgular, HIF1- $\alpha$ mRNA ekspresyonunun $0.5 \mu \mathrm{M}$ ve $1 \mu \mathrm{M}$ kurkumin ön muamelesi sonucunda, sadece $\mathrm{H}_{2} \mathrm{O}_{2}$ uygulanan gruba göre sirasiyla 1.86 ve 2.24 kat azaldığını göstermiştir. KİMKH'lerle yapılmış önceki bir çalışmada, 10 $\mu \mathrm{M}$ kurkumin uygulamasinin HIF1- $\alpha$ ekspresyonu üzerinde etkisinin olmadığ belirlenmiştir ${ }^{21}$. Elde edilen bu farklı verilerin sebebi uygulanan kurkumin dozunun oldukça farklı olmasıdır. Literatürde düşük ve yüksek doz kurkumin uygulamalarının farklı hücre içi sinyal yolaklarını etkilediği bilinmektedir ${ }^{22}$. Bu nedenle, kurkuminin osteogenez ve $\mathrm{MKH}$ tabanlı tedavi etkinliği üzerindeki etkisini daha da açıklığa kavuşturmak için in vivo çalışmalara ihtiyaç vardır.

Tüm sonuçlar göstermektedir ki; kök hücrelerin reaktif oksijen türevlerinin yoğun olduğu transplantasyon ortamına konulmadan önce kurkuminle muamele edilmesi KIMKH canlılığının korumasına yardımcı olacağı gibi, tedavi edici özelliklerinin de korunmasina yardımcı olacaktır.

Çıkar Çatışması Beyanı: Yazarlar çıkar çatışması olmadığını bildirmişlerdir.

Finansal Destek: Bu çalışma herhangi bir fon tarafından desteklenmemiştir.

Declaration of Conflicting Interests: The authors declare that they have no conflict of interest.

Financial Disclosure: No financial support was received 


\section{KAYNAKLAR}

1. Friedenstein AJ, Piatetzky-Shapiro II, Petrakova $\mathrm{KV}$. Osteogenesis in transplants of bone marrow cells. Development. 1996; 16: 381-90.

2. Leri A, Anversa P. Stem cells and myocardial regeneration: cooperation wins over competition. Circulation. 2013; 127: 165-8.

3. Park A, Barrera-Ramirez J, Ranasinghe I, et al. Use of statins to augment progenitor cell function in preclinical and clinical studies of regenerative therapy: a systematic review. Stem Cell Rev. 2016; 12: 327-39.

4. Mastrolia I, Foppiani EM, Murgia A, et al. Challenges in clinical development of mesenchymal stromal/stem cells: concise review. Stem Cell Transl Med. 2019; 8: 1135-48.

5. Zou X, Zou L, Foldager C, et al. Different mechanisms of spinal fusion using equine bone protein extract, rhBMP-2 and autograft during the process of anterior lumbar interbody fusion. Biomaterials. 2009; 30: 991-1004.

6. Burst VR, Gillis M, Pütsch F, et al. Poor cell survival limits the beneficial impact of mesenchymal stem cell transplantation on acute kidney injury. Nephron Exp Nephrol. 2010; 114: 107-16.

7. Lee JH, Jung HK, Han YS, et al. Antioxidant effects of Cirsium setidens extract on oxidative stress in human mesenchymal stem cells. Mol Med Rep. 2016; 14: 3777-84.

8. Panahi M, Rahimi B, Rahimi G, et al. Cytoprotective effects of antioxidant supplementation on mesenchymal stem cell therapy. J Cell Physiol. 2020. DOI: $10.1002 /$ jcp.29660.

9. Valle-Tenney R, Rebolledo D, Acuña, MJ, Brandan E, HIF-hypoxia signaling in skeletal muscle physiology and fibrosis. J Cell Commun Signal. 2020; 14; 147-58.

10. Karagenç N, Meydanci D, Küçüksayan H. Akciğer kanseri hücre dizilerinde hipoksi indüklenebilir faktör-1 (HIF-1) ve paraoksonaz enzim ilişkisinin araştırılması. Dicle Med J. 2015; 42: 361-67.

11. Prasad S, Gupta SC, Tyagi AK, et al. Curcumin, a component of golden spice: from bedside to bench and back. Biotechnol Adv. 2014; 32: 1053-64.
12. Phan TT, See P, Lee ST, et al. Protective effects of curcumin against oxidative damage on skin cells in vitro: its implication for wound healing. J Trauma. 2001; 51: 927-31.

13. Peddada KV, Peddada KV, Shukla SK, et al. Role of Curcumin in Common Musculoskeletal Disorders: A Review of Current Laboratory, Translational, and Clinical Data. Orthop Surg. 2015; 7: 222-31.

14. Ormond DR, Shannon C, Oppenheim J, et al. Stem cell therapy and curcumin synergistically enhance recovery from spinal cord injury. PLOS ONE. 2014; 9: 88916.

15. Mody N, Parhami F, Sarafian TA, et al. Oxidative stress modulates osteoblastic differentiation of vascular and bone cells. Free Radic Biol Med. 2001: 31: 509-19.

16. Giordano A, Tommonaro G, Curcumin and cancer. Nutrients. 2019; 11: 2376.

17. Qi Q, Li L, min Ling Z, et al. Curcumin reduces the cytotoxicity and osteogenesis inhibition induced by oxidative stress via inhibited the NF- $\kappa \mathrm{B}$ and MAPK signaling. Oncotarget. 2018; 9: 878-92.

18. Liu J, Zhu P, Song P, et al. Pretreatment of Adipose Derived Stem Cells with Curcumin Facilitates Myocardial Recovery via Antiapoptosis and Angiogenesis. Stem Cells Int. 2015; 2015: 1-12.

19. Wang N, Wang F, Gao Y, et al. Curcumin protects human adipose-derived mesenchymal stem cells against oxidative stress-induced inhibition of osteogenesis. J Pharmacol Sci. 2016; 132: 192-200.

20. Qutub AA, Popel AS. Reactive oxygen species regulate hypoxia-inducible factor $1 \alpha$ differentially in cancer and ischemia. Mol Cell Biol. 2008; 28: 510619.

21. Wang $X$, Zhang $Y$, Yang $Y$, et al. Curcumin pretreatment protects against hypoxia/reoxgenation injury via improvement of mitochondrial function, destabilization of HIF- $1 \alpha$ and activation of Epac1-Akt pathway in rat bone marrow mesenchymal stem cells. Biomed Pharmacother. 2019; 109: 1268-75.

22. Moghaddam NSA, Oskouie MN, Butler AE, et al. Hormetic effects of curcumin: What is the evidence? J Cell Physiol. 2019; 234: 10060-71. 